\title{
2005-06 Farm Bill Survey: Florida Producer Views on Rural Development; Open Space and Farmland Preservation; Labor; Research Funding Allocation; and Inclusion of Fruits, Vegetables, and Specialty Crops in Federal Government Commodity Programs ${ }^{1}$
}

Rodney L. Clouser²

\section{Introduction}

This is the second fact sheet in a series of four which describes the attitudes and opinions of Florida farm producers toward legislation that may be considered as the U.S. Congress debates the next farm bill. Florida was one of 27 states that participated in a national farm producer survey. The survey was completed in the winter of 2005-06, and the data reported are based on 244 valid and usable surveys that were returned.

Florida farm producers have participated in these surveys just prior to enactment of each new farm bill legislation since 1985 . Of the 27 states participating in the survey, five were from the South: Alabama, Florida, Georgia, North Carolina and Texas. Nationally, southern states accounted for about 30 percent of all farms included in the statistical analysis. In total, the southern and north central regions accounted for 76 percent of farms used for statistical analysis.
This fact sheet focuses on five questions that were asked specifically of Florida producers and not necessarily by the other states participating in the survey. Various socioeconomic characteristics of those responding to the survey are reported in fact sheet FE663.

Producers were asked to respond to a series of questions with responses based on a five-point scale, where $1=$ least important, $2=$ less important, $3=$ neutral, $4=$ important, and $5=$ most important. In addition, participants could answer they didn't know or had no opinion. Average scores within the five-point scale were treated as if rounded to the nearest whole number for discussion purposes. For example, an average score of 3.6 was considered "important" and an average score of 3.4 was considered "neutral."

1. This is EDIS document FE664, a publication of the Food and Resource Economics Department, Florida Cooperative Extension Service, Institute of Food and Agricultural Sciences, University of Florida, Gainesville, FL. Published October 2006. Please visit the EDIS website at http://edis.ifas.ufl.edu.

2. Rodney L. Clouser, Professor, Food and Resource Economics Department, Florida Cooperative Extension Service, Institute of Food and Agricultural Sciences, University of Florida, Gainesville, FL.

The Institute of Food and Agricultural Sciences (IFAS) is an Equal Opportunity Institution authorized to provide research, educational information and other services only to individuals and institutions that function with non-discrimination with respect to race, creed, color, religion, age, disability, sex, sexual orientation, marital status, national origin, political opinions or affiliations. U.S. Department of Agriculture, Cooperative Extension Service, University of Florida, IFAS, Florida A. \& M. University Cooperative Extension Program, and Boards of County Commissioners Cooperating. Larry Arrington, Dean 


\section{Rural Development Preferences}

Five questions were asked of producers regarding rural development programs. All questions were ranked in the range of 3.4 to 3.9. Highest ranked was the need for improved education and training programs (3.9). This indicates respondents believed this issue was important. Producers also believed it was important (3.7) to improve access to capital for business and growth in rural areas. From the responses, it appears producers also thought increases in grants for business development and job creation in rural areas of Florida (3.7) were important. Finally, support for expansion of high-speed and internet access in rural areas slightly leaned toward being classified as important (3.6) by survey respondents. Only one of the five questions asked leaned toward neutral support (3.4), which was the need for increased infrastructure in rural areas of Florida. This most likely indicates there are needs in some areas, but the majority of respondents felt this was less important than the other programs mentioned. It is interesting to note that less than seven percent of producers answered "don't know" on every rural development question, except one. That question dealt with the provision and availability of high-speed internet services. With just over 10 percent answering "don't know" to this question could imply that high-speed access is not that important for their particular use or that they may not use or have computer knowledge regarding this issue.

\section{Open Space and Farmland Preservation}

Producers were asked five specific questions regarding policy tools and their preferences among those tools that would encourage open space and farmland preservation (Table 1). Responses for the five questions ranged between 2.6 and 3.9. The only policy tool that generated much support as being important in this area was government funding for entrepreneurial tools that would make farm and food production more competitive with non-farmland use (3.9).

On the other extreme, support for funding that would allow for purchase of development rights from farmland and transferring those rights for development in other areas was less than neutral and somewhat lukewarm (2.6). This could reflect a true lack of support for this policy tool, or it might reflect that farm producers lack technical knowledge regarding this alternative. This latter point is further reinforced by the fact that 12 percent of respondents indicated they didn't know/had no opinion regarding this policy alternative. Two other policy alternatives were neutral in terms of importance. Federal funding for purchasing development rights and conservation easements (3.0) and privately-funded programs that purchased development rights and conservation easements by groups such as foundations (3.1) were not viewed as important policy alternatives. The last policy alternative, voluntary donation of conservation easements to foundations or conservation areas, was considered a slightly more viable policy tool for open space and farmland preservation by Florida producers (3.5).

\section{Labor Issues}

Labor is not one of the ten titles of the 2002 Farm Bill; however, the nature of farm production, specifically the state's fruit and vegetable industry, makes labor issues important in Florida. Four specific questions were asked addressing this topic, and producers responded to how important it was to address these issues "with federal policy." It must be noted this does not imply that labor issues should or would be addressed in the next Farm Bill. Florida producers responded that policy issues with respect to availability of seasonal labor (3.9) and availability of full-time labor (3.9) from a federal perspective were important. This was not surprising, considering the national debate regarding immigration reform and the last two hurricane seasons, which may have channeled agricultural laborers to the hurricane recovery efforts rather than work in the agricultural sector. Florida producers responded in a more neutral position with respect to needs for federal policy to address the foreign guest worker program (3.3) and public services and needs in communities with immigrant agricultural workers (3.2). This latter issue, if asked of farm workers or farm worker advocacy groups, might result in a much different response to the need for federal policies. 


\section{Allocation of Research Funds}

Survey respondents were asked 12 questions related to the allocation of research funds if funds were available (Table 2). Nine questions had responses that ranged between 3.8 and 4.3 points, indicating the areas were important in terms of possible research funding. Topping the list was the research area of biofuels and renewable energy (4.3). With the recent rapid rise in fuel costs, which translate into higher production costs for agriculture, the importance of this topic might have been expected. More surprising is that the topic ranked second-highest in terms of importance in the allocation of research funds was food safety (4.3). However, when you consider Florida's agriculture production industry and all the concern since $9 / 11$ of a possible terrorist attack on the food production industry, it can be understood why this issue is important to Florida producers. Issues such as "mad cow disease" (one incidence in the South) could also help explain the importance of this topic to Florida producers. The third most important area for research-dollar allocation, water quality (4.3), has been an important topic in Florida for many years and is considered important for research funding.

The six closely grouped areas that are important for research-funding allocation closely followed the top three areas, with a range of importance ranked between 3.8 and 4.0. Producers still consider the allocation of research funding to production agriculture (4.0) an important issue. This may be heavily influenced by problems with disease in Florida in recent years specifically related to citrus production. Identified next in terms of importance in research-funding allocation was the program area of food security (4.0). This program area is closely linked to the food safety area, which in terms of importance is even ranked higher. Next in importance to Florida producers was the topic area of soil quality (4.0). Florida has many unique lands which are sandy and well-drained, flatwoods soils that are poorly drained, or muck soils in the southeast portion of the state that have been subsiding over time. Use of fertilizers and other chemicals are also being closely monitored by farm producers, external advocacy groups concerned with applications, water management districts, and local and state governments. This may help explain the importance of soil quality research. The final three programs in this closely grouped area are air quality (3.9); biosecurity of plant, animal, and food systems (3.8); and biotechnology (3.8).

The last three areas related to research-funding allocation all had rankings between 3.3 and 3.6. The importance for research-funding allocation for private forest land management, nutrition and obesity, and community and economic development was between neutral and important. The most important information assembled from this question may be that out of all 12 research-funding areas producers were questioned about, none were identified as being less or least important.

\section{Inclusion of Fruits, Vegetables, and Specialty Crops in Federal Commodity Programs}

Producers were asked which federal programs would be most preferred if federal funding was available, with fruits, vegetables, and specialty crops included in government commodity programs. Florida producers only ranked one program in the "important" category, and that was disaster assistance (4.2). Since Florida has had several disasters (primarily hurricanes) over the last two years, the importance of this issue is clear. Two other programs were ranked between neutral and important: risk management programs [i.e., subsidized crop insurance] (3.5) and federal block grants available to states for state-level programs for fruits, vegetables, and specialty crops (3.4). This latter alternative most likely suggests that Florida producers are more comfortable with programs developed and regulated at the state level with federal dollars rather than programs developed and regulated by the federal government.

All other alternatives for inclusion of fruits, vegetables, and specialty crops in federal commodity programs were ranked between "less important" and "neutral." There was limited support for direct payment programs (2.7), such as paid land diversion, storage payments, and deficiency payments. Support (2.8) was not much stronger for countercyclical payments (funds increase when prices are low and 
decrease when prices are high) as an alternative among Florida producers. There was slightly higher support (2.9) for programs that would consider both commodity price and production levels.

\section{Summary}

Florida producers identified the importance of several different policy alternatives related to the topics in this fact sheet. Increased training and educational programs related to rural development were important. Entrepreneurial tools that make food and fiber production more competitive with non-farm uses of land was considered an important issue.

Addressing issues at the federal level with seasonal and full-time agriculture labor supply, so critical to the state, is an important issue. While allocation of research funds in all 12 program areas producers were asked to assess was neutral or higher in all areas, the highest ranked area was biofuels and renewable energy. Finally, if fruits, vegetables, and specialty crops were made part of federal farm programs, producers expressed the most important issues were risk management tools and federal block grants to states for state-level policy alternatives.

\section{References}

Clouser, Rodney L. 2006. 2005-06 Farm Bill Survey: Characteristics of Florida Producers Who Participated. Electronic Data Information Source (EDIS) FE663. Food and Resource Economics Department, University of Florida, Gainesville, FL. http://edis.ifas.ufl.edu/FE663.

University of Arkansas. Glossary of Agricultural Production, Programs and Policy, Fourth Edition. http://agglossary.uaex.edu/viewAGlossary1.asp. Website visited July 2006. 
Table 1. Producer views on open space and farmland preservation.

\begin{tabular}{|c|c|}
\hline Policy Alternative & $\begin{array}{l}\text { Average } \\
\text { Response }\end{array}$ \\
\hline $\begin{array}{l}\text { Increase federal funding for programs that purchase development rights and conservation } \\
\text { easements }\end{array}$ & 3.0 \\
\hline $\begin{array}{l}\text { Reduce federal funding and emphasize privately-funded programs that purchase development } \\
\text { rights and conservation easements }\end{array}$ & 3.1 \\
\hline $\begin{array}{l}\text { Provide federal supports and/or grants to local governments that allow developers to purchase } \\
\text { development rights in certain areas in exchange for developing other areas (allow transfer of } \\
\text { development rights) }\end{array}$ & 2.6 \\
\hline $\begin{array}{l}\text { Encourage voluntary donations of conservation easements and/or land donations to } \\
\text { conservation areas/foundations }\end{array}$ & 3.5 \\
\hline $\begin{array}{l}\text { Support entrepreneurial programs designed to make farm and food production more } \\
\text { competitive with non-farmland uses }\end{array}$ & 3.9 \\
\hline $\begin{array}{l}1=\text { least important } \\
2=\text { less important } \\
3=\text { neutral } \\
4=\text { important } \\
5=\text { most important }\end{array}$ & \\
\hline
\end{tabular}

Table 2. Research funds allocation.

\begin{tabular}{|c|c|c|c|}
\hline Research Area & $\begin{array}{c}\text { Average } \\
\text { Response }\end{array}$ & Research Area & $\begin{array}{c}\text { Average } \\
\text { Response }\end{array}$ \\
\hline Biofuels \& Renewable Energy & 4.3 & Nutrition \& Obesity & 3.5 \\
\hline Biotechnology & 3.8 & Air Quality & 3.9 \\
\hline Production Agriculture & 4.0 & Soil Quality & 4.0 \\
\hline Biosecurity & 3.8 & Water Quality & 4.3 \\
\hline Food Security & 4.0 & Private Forest Land Management & 3.6 \\
\hline Food Safety & 4.3 & Community \& Economic Development & 3.3 \\
\hline $\begin{array}{l}1=\text { least important } \\
2=\text { less important } \\
3=\text { neutral } \\
4=\text { important } \\
5=\text { most important }\end{array}$ & & & \\
\hline
\end{tabular}

